\title{
CREB-Regulated Transcription Coactivator 2
}

National Cancer Institute

\section{Source}

National Cancer Institute. CREB-Regulated Transcription Coactivator 2. NCI Thesaurus. Code C95455.

CREB-regulated transcription coactivator 2 ( $693 \mathrm{aa}, \sim 73 \mathrm{kDa}$ ) is encoded by the human CRT C2 gene. This protein is involved in the modulation of transcription. 